Paulina Wężniejewska

ORCID: 0000-0001-8529-771X

p.wezniejewska@wp.pl

Oskar Szwabowski

ORCID: 0000-0002-7464-0081

o.szwabowski@gmail.com

Monika Stodolna

ORCID: 0000-0001-7865-300X

monika.b.lozinska@gmail.com

Uniwersytet Szczeciński

\title{
Dydaktyka na scenie. Autoetnografia performatywna performansów studentów i wykładowcy
}

\section{Przed albo po}

Szanowni i Szanowne! Zapraszamy was do czasu zastygniętego. To, co było ucieleśnione, teraz zawarte jest w słowach. Nasza performatywna autoetnografia (Spry 2001; Denzin 2003a, 2003b; Pelias 2005) stała się performatywnym pisaniem (Saldaña 2006) - oddzielona od ciał może ożyć w waszych słowach, które przepłyną przez jelita, wstrząsając organizmem. Albo osiądą na wątrobie i powoli będą trawione. To, czy to pozostanie martwym artefaktem, zależy od was. Zostawiliśmy wam miejsce - w słowach i pomiędzy słowami (Guttorm 2012). Performance to przede wszystkim tworzenie wyzwolonej przestrzeni (czy przestrzeni dla wyzwolenia) i rzucanie wyzwania zastanym formom życia (Denzin 2017).

Kiedyś napisaliśmy, że to jest przykład performatywnej autoetnografii. Przykład? W jakim sensie? Model paradygmatyczny dla szalonej twórczości autoetnografów? Lepiej chyba mówić o przejawie - zjawieniu się w Gdańsku, na scenie, a potem na stronie. Która dalej jest sceną - zobaczcie, usłyszcie.

Poniższy tekst składa się z dwóch części. Pierwsza - Spotkania dotyczy momentu tworzenia wystąpienia, druga - Na scenie to zapis wystąpienia, scenariusz, który powstał. W powstaniu pierwszej wersji tekstu udział mieli Oskar i Paulina. Monika 
dołączyła na scenie - potem poprosiliśmy o jej głos, skoro już go wykorzystaliśmy, tak samo jak jej ciało, zmuszając do odgrywania scenariusza wraz z nami.

Na scenie użyliśmy zapisów z innych tekstów (Szwabowski, Wężniejewska 2017; Szwabowski 2019). Zostały one zmodyfikowane. Zwłaszcza głos Oskara ulegał transformacji przez uwzględnianie perspektywy Pauliny - studentki, która uczestniczyła w projekcie. Zresztą to ona jest winna temu, że zrobiliśmy autoetnograficzny performance zamiast „normalnego” opisu i konferencyjnego doświadczenia. Konferencja dotyczyła dydaktyki akademickiej. Najpierw mieliśmy przedstawić klasyczny raport. Jednak po pierwszym spotkaniu stwierdziliśmy, że byłaby to zdrada idei, w imię której powołany został projekt.

\section{Spotkania}

Siedzimy w pokoju na Ogińskiego, Instytut Pedagogiki, za oknem powoli zapada zmrok, a po korytarzu snuje się jedynie pani z mopem. Wokół notatki, poprzednie teksty, moje, wspólne, studentów, dziennik projektu. Siedzimy, wycinamy, sklejamy. Trzeba to przedstawić tak, jak było. W każdym tekście inna wersja. Jestem trochę nerwowy. Zawsze jestem nerwowy, gdy przygotowuję się do wystąpienia na konferencji. „Co ich może zainteresować?” - myślę na głos. „Trzeba jakoś skoncentrować się na dydaktyce. Monika mówiła, że oni są bardzo praktyczni. Rady i porady. Behawioryzm rządzi”. Paulina słucha. Ja rozkładam ręce. „Przecież to nie była technologiczna dydaktyka (Malewski 2010). To, no nie wiem, to... mógłbym im dać radę, aby tego nie robili. A tak serio, to przecież nawet jakby się udało ukazać krok po kroku, co robiłem, to i tak nic by to nie dało. Jak chciałem powtórzyć, rok później, mówię, będzie lepiej, to okazało się, że jest gorzej. Nigdy nie wiem, jak działam, co się dzieje w ludzkich głowach. Wiesz: «Teaching is messy. Dealing with other people is always tricky: You never know for certain what they are thinking or how they will act» (Waite 2014: 267). To jest - każde spotkanie dydaktyczne, coś pojedynczego. Wyjątkowego. Chociaż nie zawsze pozytywnego". Paulina słucha, przytakuje.

Pyta mnie: „Co to było? Powiedz mi, czym był ten projekt?”. „Nie wiem - odpowiadam. - Nie wiem, co się działo, nie wiem, o co w tym wszystkim chodziło". Sprzeczne interpretacje majaczą nieustannie w głowie. „Wiesz, wymyka mi się”. Już tyle o tym pisaliśmy, a ja wciąż nic nie wiem. „Czym to było dla ciebie?” - Paulina nie odpuszcza. „Jakie to miało znaczenie dla ciebie. Tak naprawdę. Jest już późno, mów szczerze, dlaczego zacząłeś prowadzić zajęcia zupełnie inaczej”. Nerwowo poprawiam okulary. Zdejmuję, przecieram. Chcę powiedzieć, że nie pamiętam. Po chwili myślę, że może zrobię miniwykład o tym, że dydaktyka transmisyjna to takie uszkolnienie uniwersytetu, że to szkolenie do zawodu, martwa wiedza, że to podporządkowywanie pod to, co jest, pod neoliberalizm. Kiedy spotkałem się z autoetnografią, dostrzegłem jej potencjał dydaktyczny (zob. Boyd 2008; Sykes 2014; Ciechowska 2017; Barr 2018; Blalock, Akehi 2018). Nie zawsze udawało mi się go 
wydobyć w trakcie zajęć. Uczyć autoetnografii i poprzez autoetnografię, z miłością, aby zmieniać świat (Ulmer 2017) - ten cel jakoś mi się wymykał.

„Dobra - mówi Paulina, wyrywając mnie z zamyślenia - to może napisz o tym, dlaczego zacząłeś prowadzić zajęcia inaczej i zobaczymy”. Patrzę na plan, który zarysowaliśmy. „My już o tym pisaliśmy” (zob. Szwabowski 2019; Szwabowski, Wężniejewska 2017; Kaczmarczyk et al. [w druku]) - szepczę. To wszystko to jest powtórzenie. Chociaż, gdy patrzę na materiały, gdy je roboczo składam, to wyłaniają się kolejne sensy. Pisząc o projekcie, za każdym razem tworzyliśmy inną historię. Tak, wiem, pisanie nie jest czymś neutralnym (Denzin 2009). Nasze zapiski nie są też danymi, które otworzą prawdę, gdy zastosuje się wobec nich określoną praktykę (zob. Pławski et al. 2019). Są śladami przywołującymi zróżnicowane wspomnienia. Tak jak głosy studentów, wcześniejsze nasze wspólne opowieści - zapraszają duchy, które prowokują nas do mówienia.

„To może to pokażemy” - rzuca Paulina. „Dasz radę?” Wzruszam ramionami. To dobry pomysł. „To ja zrobię scenariusz. Widzimy się online”. „Dobra, zróbmy to, wykreujemy coś nowego. To chyba będzie lepsze” - odpowiadam. „Inaczej popadniemy w narrację, w sposób prezentacji, który jest sprzeczny z naszymi założeniami”. Patrzę na szkic, ślady pragnienia technologicznego, podania przepisu na dobre zajęcia. Dopasowanie się do publiczności. Nie, performatywna autoetnografia to prowokacja. "Autoetnografowie nie tylko są nawiedzani, ale też nawiedzają" (Herrmann 2014: 329).

Następne spotkanie. Ten sam pokój. Przed nami wydrukowany scenariusz napisany przez Paulinę. Czytamy najpierw cicho, każdy dla siebie. Później, podczas prób, gdy wypowiadam słowa, gdy słyszę jej słowa, słowa studentów, których widma przywołuje, wtedy czuję się dziwnie. Odnoszę wrażenie, że utraciłem władzę nad opowieścią, że moje ja w tym przedstawieniu jest obrazem, od którego chciałbym uciec. Czy rzeczywiście działałem tak, jak opisuje to Paulina? Ona była wewnątrz, wśród studentów, słyszała głosy, których nie słyszałem, spoglądała na mnie, kiedy

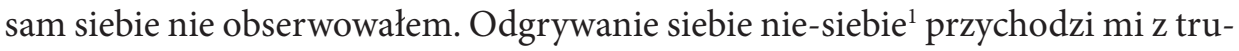
dem. Ten obraz... nie podoba mi się. Tak jakby duchy wywołane przez Paulinę przypominały o wypartej, wstydliwej opowieści.

W trakcie przerwy palimy papierosa przed budynkiem uniwersytetu. Przed nami park. Jest ciepło, majowe powietrze, rodziny spacerujące z dziećmi. „Naprawdę tak działałem?” - pytam Paulinę. Przytakuje. „Nie było aż tak źle. Lepiej niż gdy spotkaliśmy się na pierwszych zajęciach”. Pierwsze zajęcia, pierwszy rok mojej pracy. Dostałem ćwiczenia z dydaktyki i nie wiedziałem, co na nich robić. Lęk oddzielał mnie od studentów. Byli dla mnie masą, która co najwyżej stanowi zagrożenie. Za drugim razem, po trzech latach... „Chociaż wyglądałeś na zmęczonego” - dodaje

Chodzi o napięcie wyłaniające się z przyjmowania pewnych roli - self - gdzie „ja” próbuje być „ja” akademickim. W tym wypadku obcość pojawia się w pełni, gdy próbuję przywołać siebie, którego już nie ma, bo sieci, które go/mnie stworzyły, są tylko wspomnieniem. Oszukuję więc siebie i innych, opowiadając, kim jestem i kim byłem, próbując przekonać publiczność, że taki jestem/byłem. 
po chwili Paulina. „Bo byłem - odpowiadam. - Miałem kryzys, dlatego podjąłem się tego projektu. Nie mogłem już dłużej prowadzić zajęć jak wcześniej. Gdybym niczego nie zmienił... No, nie dawałem rady". Autoetnografia nie tylko pozwoliła mi odrodzić się jako badaczowi, przywrócić wiarę w sens pisania i nauczyła innego pisania, ale też była dydaktycznym zmartwychwstaniem, czymś, co otworzyło mnie na piękno dydaktyki i pozwoliło praktykować inną edukację, dokonywać sabotażu neoliberalnej maszyny dydaktycznej. Mimo świadomości, że rozpoczynałem projekt w czasie kryzysu, że w sumie był to dla mnie proces stawania się innym dydaktykiem, gdzie stare nawyki wciąż funkcjonowały, nie podobał mi się mój obraz przedstawiony przez Paulinę. Irytowało mnie trochę, że utraciłem władzę nad narracją o projekcie, o sobie. Możliwe, że dlatego teraz piszę to wprowadzenie. By odzyskać narrację, znowu stać się kierownikiem i strażnikiem sensu. Zawsze to ja pisałem pierwsze i ostatnie słowo - siebie i innych. „Idziemy?” - pyta Paulina, gasząc papierosa. „Czas na próbę”. Przytakuję.

Później, Gdańsk, konferencja. Tworząc scenariusz, mieliśmy w głowie zwykłą, typową salę wykładową. Wchodzimy: wielka aula, jak z antycznego teatru. Słuchamy wystąpień. Prezentacje multimedialne, klasyczna struktura, ładnie to wszystko uporządkowane i konkretne rady na koniec. „Boję się tego wystawienia, bycia na scenie", szepcze Paulina. Udaję, że wszystko jest dobrze, chociaż mam ochotę uciec. $\mathrm{W}$ przerwie trzęsą mi się dłonie. Palimy nerwowo papierosa za papierosem. Niedługo my. Wydaje mi się, że chyba pomyliliśmy konferencje. Słyszymy, jak należy poruszać się po sali i jak pracować głosem, aby utrzymywać mózg studentów w stanie nieustannej koncentracji. Ktoś inny mówi, jak dobrze używać Power Pointa w trakcie zajęć. Ile tekstu na slajdzie, jak slajdy połączyć z tym, co się mówi. Mamo...

Tekst został stworzony przez Paulinę i Oskara na podstawie wcześniejszych zapisów, wspomnień i snów/koszmarów/majaków. W wystąpieniu udział wzięła Monika Stodolna.

Monika: „Wkręcili mnie w to. Na ostatnią chwilę, na szybko, na wariata. Mówią: «Masz tu tekst, kilka linijek, będziesz i tym, i tym, i tamtym, dobra?». No dobra. Jestem kilkoma osobami, muszę pilnować nie swojego tekstu, nie swoich myśli i odegrać to przed salą pełną wpatrzonych w nich oczu (ja siedzę z publicznością, mam być jakimś przerywnikiem, elementem wybijającym z rytmu publiczność). Jestem także widzem. Tyle ról i pozycji.

Najciekawsze jednak to być patrzącym i słuchającym w zdumieniu tego, co odgrywa się na scenie, na tę zewnętrzno-wewnętrzną bitwę dwóch światów - studentów i wykładowców. Fascynujące. 
Poprzednie edycje Ideatorium utwierdzały mnie w przekonaniu, że tam liczy się metoda, tylko ona. Szerszy kontekst, jakieś paradygmaty nie mają sensu, tylko metoda, tylko technologiczne zastosowanie tego czy tamtego. Nie patrzmy w siebie, a już z pewnością nie w studenta. Cel, działanie, efekt, ewaluacja. Dydaktyka jako działanie. A tu Oskar i Paulina... Inny świat”.

\section{Na scenie}

OSKAR - wykładowca

PAULINA - studenci

MONIKA - dziekan, profesor, student

\section{Lekcja 1}

Temat: Autoetnografia

Sala. Ławka, na przeciw niej biurko. Publiczność raz jako tłum studentów, raz jako publiczność. Gdzieś na stole kartki i książka z etykietą "promocja, oddam za darmo..." OSKAR

(układając notatki na stole, przeszukując książki, zapisując coś na tablicy kartce) Sceptyczny wobec uniwersytetu i jego produkcji wiedzy - uniwersytetu, który jest raczej ponurą fabryką, gdzie nikt nie organizuje radosnych spotkań-strajków. W takiej fabryce, myślałem, nie istnieje dydaktyka, która wyzwala. Moja dydaktyka zresztą była beznadziejna. Powiedzmy: typowa. Metodą podająca nauczałem konstruktywizmu. Krytycznego myślenia uczyłem, wykładając właściwą interpretację określonych filozofów. Nie wiedziałem, że w praktyce wspierałem neoliberalną maszynę. A pragnąłem utopii, innej edukacji - coś musiało się zmienić.

\section{PAULINA}

(mówi, wchodząc) Dzień dobry.

\section{OSKAR}

(mówi od niechcenia, patrząc na rzeczy rozłożone na biurku) Dzień dobry. PAULINA

(siada z boku. Wyciagając przybory, opowiada) Pamiętam tego człowieka. Trochę szalony albo chory. Tak... Choroba wydaje się być bardziej zasadna... Coś go dręczy, rozrywa... Rozpala, by zgasić za chwilę. Zaraz zacznie. Widać, że coś uknuł... Że ma już jakiś plan naprawy świata.

OSKAR

Chciałbym, abyście napisali książkę...

PAULINA

Jednak szalony. 


\section{OSKAR}

Chciałbym, abyście, abyśmy, zrobili coś innego, coś sensownego.

\section{STUDENT}

Dobrze się dowiedzieć, po paru latach, że to, co robiliśmy przedtem, było bez sensu... tak mamy to rozumieć?

OSKAR

Nie... to znaczy... tak.

PAULINA

(do publiczności) Jest to doskonały przykład tego, jak nie zaczynać rewolucji w myśleniu.

OSKAR

Pisaliście licencjat, pisaliście liczne prace - i po co? Dla siebie? Dla oceny? Dla wymagań wykładowcy, promotora, instytucji? To były wasze słowa? Was stwarzające? Czy to pisanie miało znaczenie? Słowa były żywe?

Przywróćmy słowu życie. Studiowaniu egzystencjalne znaczenie. Wiecie, zróbmy coś, co nie będzie pozorem. Badając siebie w kontekście bycia studentem. Pisząc, badając, by tworzyć zmianę. Wspólnie - stwórzmy kolektywną autoetnografię studiowania. Wielogłosową zróżnicowaną opowieść.

(do publiczności) Mam wizję, halucynacje, że się zbierają i dyskutują, krąg ciał w sali i niekończąca się debata, zapada zmrok i studiowanie się zaczyna.

Paulina podnosi rękę. Oskar gestem udziela głosu.

PAULINA

A to na ocenę?

OSKAR

Wszystkie kryteria są polityczne (Adams, Jones, Ellis 2015). Uciszają jednych, delegitymizują, innych zaś legitymizują - jako głosy rozsądne, i tak dalej. To, co chcę, to usłyszeć państwa głos. Nie mam narzędzi do jego oceny.

(po chwili) Co państwo na to? Zrobimy to?

\section{PAULINA}

(do publiczności) Niepewność. Że to jakiś żart i nie chodzi tu o nas.

Nieufność. Że to jakiś tani eksperyment.

Wszystko na nie! Więc...

(do Oskara) Zgadzamy się wziąć udział.

(do publiczności) Jak zawsze... zresztą.

OSKAR

Dobrze.

(do publiczności) Wiem, wiem, nie wiedzą, co czynią.

(do studentów) W takim razie proponuję zaplanować dalsze prace.

\section{PAULINA}

(do Oskara) No to proponuj... a najlepiej...

(do publiczności) Niech pan zaproponuje jakieś inne formy zaliczenia.

Nie każdy przecież lubi pisać. 
A i tak nie wiadomo, o jakie pisanie chodzi.

Jak to mamy napisać? Jakiś wzór? Jakieś wytyczne?

(pod nosem ze smutkiem) A najlepiej jakaś kalka.

OSKAR

(podchodzi do biurka, opiera ręce - jakby chciał dodać odwagi czy czegoś)

To nie jest metoda, którą można rozpisać w technicznych krokach. To coś jak pisanie opowiadań. Opowiadanie historii. To, jak państwo je opowiedzą, zależy od państwa, jest tu dość duża dowolność.

(odchodzi na środek, Paulina zaczyna notować)

W gruncie rzeczy są one idiomatyczne (Kubinowski 2013; zob. również Wilker 2018).

PAULINA

(zapisuje, mówiąc pod nosem) Idiotyczne...

OSKAR

(głośniej) Nie ma wzoru. Raczej powinni państwo kierować się własnym, niepowtarzalnym głosem, własnym stylem. No i nie bać się eksperymentowania.

To jest eksperymentalne pisanie.

PAULINA

A ile stron?

OSKAR

Zależy od autora - to musi mieć sens po prostu. Ale - ministerstwo daje formalne wymagania co do książki: to jest około 120 stron.

PAULINA

To damy dużą czcionkę.

OSKAR

Zostawmy to wszystko na razie. Może jaśniejsze się staną te kwestie w trakcie. Przeczytają państwo o autoetnografii na następne zajęcia. I zastanowią się, co chcą powiedzieć.

Oskar staje na środku sceny. Paulina staje z boku, trochę z tyłu.

OSKAR

Zmęczenie bycia maszynką plującą tekstem - powielającą to, co już zapisane: teksty podręcznika, własne artykuły, przeczytane książki. Maszyna kopiująco-mówiąca - czas mija, jest dobrze. Zmęczenie.

Mówiąc, walczę ze zmęczeniem, jakbym spod gruzów martwych słów wydobywał te, w których się coś tliło.

Jednocześnie: niepewność. Co tak naprawdę chcę zrobić? Kilka zdań naszkicowanych, w przerwie, drżącą dłonią, kilka idei majaczących - piszcie autoetnograficzne teksty, bądźcie krytyczni, drapieżni... A oni, oni chcą instrukcji, krok po kroku, tak są uczeni, że metoda to maszynka, technika gromadzenia, analizowania i przetwarzania danych, która sprawia, że wytwory są prawdziwe, odpowiednie, poprawne, o, takie na piątkę. Widzę, jak boją się poruszać. Wykonywać gesty, formułować słowa. Czy to pasuje, pasuje do wzoru? 


\section{PAULINA}

Jakieś dziwne to wszystko - dziwne są te całe zajęcia. Ale nie ma co się dziwić, skoro jakiś dziwny człowiek prowadzi je w jakiś dziwny sposób. Dziwnie mówi, dziwnie patrzy, dziwnie chodzi. Momentami wydaje się, że nawet dziwnie oddycha. O ile jeszcze oddycha...

I już nie wiemy, czy to tak dla śmiechu, czy na poważnie. I już nie wiemy, o co w ogóle w tym całym Uniwersytecie chodzi... Mimo wszystko wkrada się jakaś niechciana radość, że tym razem będzie inaczej...

Jako studenci nie jesteśmy jednak jednym zgodnym obozem. Nie jesteśmy masą. Mamy różne głosy...

PAULINA (jako studenci)

(za Oskarem raz z lewej, raz z prawej, jakby do ucha)

Bezsensu...

To ma sens...

Nic nie rozumiem.

Wszystko jasne.

Może... nas wkręca?

Może nam wierzy?

Może szuka czegoś dla siebie?

Może chce zrobić coś dla nas?

Miły człowiek...

Źle mu z oczy patrzy...

Coś bierze...

Powinien coś wziąć...

Wariat albo chory.

W końcu ktoś normalny...

Oskar siada za katedrą. Paulina w ławce. Wyglądają na zmęczonych.

OSKAR

Na razie mi się rozmywają twarze, wielość ciał bez wyrazu.

Mówię - zajęcia pierwsze, zajęcia drugie, zajęcia trzecie - a miałem nie mówić, tylko słuchać.

Mówię - i mam wrażenie, że słowa ich omijają.

Że wpadamy znowu w to-samo.

Mówię - i jest tak cicho.

Mówię - bez słów.

PAULINA

Mówi i mówi, i mówi. Lepiej się nie odzywać.

Już wszystko wie...

Niby pyta. Ale...

Ucichł. Czeka... Niech czeka... Dobrze się milczy w dobrym towarzystwie, ale... to trwa już za długo.

A i tak nie wytrzyma... (patrzy na zegarek, którego nie ma) 


\section{OSKAR}

Co to jest autoetnografia?

\section{PAULINA}

Nie mówiłam...

A tak, mieliśmy przeczytać...

Jedna osoba czytała...

Jakby to powiedzieć...

Autoetnografia to...

(do publiczności)

Najważniejsze to unikać kontaktu wzrokowego.

Patrzeć w kartkę...

Przeglądać notatki...

W końcu się podda...

Sam wszystko powie...

I wszystko powie oczywiście lepiej niż my.

Nie myślcie, że jesteśmy tacy źli. Ktoś coś wie. Ale głupio tak mówić, a jak się źle powie? Przecież wiesz, że tamten co pyta, wie, i wiesz, że on wie, że ty do końca jeszcze nie wiesz...

OSKAR

I ja nie wiem - nie wiem już, dla kogo robię ten projekt - kto go robi i po co - są chwile, że myślę, że tylko mi na tym zależy...

Już tylko efekt: by powstała książka - kolejne kompromisy, a nie porozumienia - raczej nieporozumienia.

Wpadanie w to-samo.

Myślę, że zbyt to chaotycznie prowadzę, coś nie tak - innym razem będzie lepiej.

(do publiczności)

Nie było.

\section{PAULINA}

Wszystko szybko... nawet teraz.

Tik tak. Zegar odmierza czas naszej edukacji.

A my potrzebujemy czasu, ale po to, by odszkolnić nasze myślenie.

Tyle lat spędzonych w szkole sprawia, że człowiek traci wiarę w edukację...

Bo nie jesteśmy tacy, jacy mieliśmy być.

Bo nie jesteśmy tacy, jacy chcieliśmy być.

\section{OSKAR}

Też potrzebuję czasu - aby się stawać: wyzwalać od instrumentalnego, menedżerskiego myślenia, od złego pragnienia dydaktycznego: organizować, nadzorować, stwarzać według wzoru i celu. To-samo nawiedza niczym złośliwy upiór. Tak jakby cały projekt zależał ode mnie. Ja odpowiedzialny za wszystko, a oni - studenci - znowu stają się masą przedmiotów do manipulacji. Pozór dialogu, pozór 
współpracy - nawiedza mnie melancholia: utrata studentów jako przedmiotu? Iluzje: automobilni² (zob. Lordon 2012) studenci realizujący scenariusze.

\section{PAULINA}

Nie każdy chce mówić od siebie.

Nie każdy wie, jak mówić.

Kultura milczenia (Stańczyk 2010)

pozwala zapomnieć,

czym jest słowo.

OSKAR

Powoli wyłaniają się twarze,

na ile są to twarze, które mówią,

a na ile przedmioty, nad którymi trzeba zapanować, które trzeba opanować którymi trzeba zarządzać raz miękko, raz militarno-fordystycznie - aby otrzymać efekt pod postacią książki? Waham się, spojrzenie moje przeskakuje - widzę to raz tak, a raz tak.

Twarze i mordy.

Pojedyncze głosy, nieśmiałe, w duszącej ciszy.

I głosy - odczep-się-pan-zrobiłam-już-swoje.

A może...

PAULINA

(podchodzi do Oskara z kartkami) Czekam na wyrok. OSKAR

Czytam pierwsze wersje i... Gdzie są wasze głosy?

PAULINA

(pokazujacc palcem) Tutaj i tu, i tu. (pochyla się) A nie, tu kłamałam.

\section{Lekcja 2}

Temat: Głosy

Oskar stoi pośrodku sali. Rozgląda się wokót.

PAULINA

Snuję opowieść, byś się odczepił. Sama nie wiem, po co tu jestem, po co mówisz do mnie i po co mamy ze sobą rozmawiać. Niby dlaczego mam mówić od siebie, to nie jakaś tam grupa terapeutyczna. Czy rzeczywiście muszę oddać władzy wszystko, nawet siebie, pod pozorem jakiejś emancypacji, mam się otwierać przed obcym, obnażać swoje uczucia, zapuszczać się w najintymniejsze rejony, bo on chce dostępu do tego, co moje - prywatne, intymne? Tu nie ma wspólnoty. Tu nie ma przestrzeni dla mojego i innych głosu. Czy można być szczerym w tłumie?

2 Odwołujemy się do rozumienia dydaktyki jako procesu zarządzania, w którym pozornie emancypacyjne sposoby wiążą się z działaniem na pragnienia i czynieniem ich współliniowym z pragnieniem nadrzędnym, pragnieniem nauczyciela (zob. Szwabowski 2016). 
MONIKA (jako dziekan)

(podchodzi do biurka ze złościa) Doszły mnie niepokojące głosy, że pan każe studentom pisać i publikować teksty krytyczne wobec naszego uniwersytetu. Renoma uniwersytetu jest najważniejsza, rozumie pan. To nas niepokoi, to wasze pisanie, bardzo niepokoi, jeżeli wie pan, co mam na myśli.

(znika w mroku)

PAULINA (jako inny student)

Uniwersytet jeszcze istnieje! Jeszcze jest w nim miejsce dla wspólnego tworzenia wiedzy.

MONIKA (jako profesor)

Ich prawdziwe opowieści są gdzieś indziej, niż myślisz. To nie teksty, które czytasz. Ich autoetnografia to strategie omijania twojego projektu przez branie w nim udziału. To wszystko, co dzieje się obok.

PAULINA (jako jeszcze inny student)

Wymykam się opowieścią. Milczenie jest moim schronem. Moim wyzwoleniem od nakazu mówienia, który później taki Szwabowski ocenia, waży, rozważa, w tych swoich emancypacyjnych ponoć laboratoriach. Odbiera mi historię albo, kiedy mówię, przekształca ją, by się zgadzały z jego myśleniem o wolności. MONIKA (jako student)

Mówisz, że nie jest to mój głos, że ci się nie podoba to, co napisałam. A może to właśnie jest mój głos. Może tak snuję narrację. Może takie jest moje istnienie. Takie brzydkie dla ciebie. Dla twoich kolegów i koleżanek z akademii. Zbyt płaskie. Mało subtelne.

PAULINA (jako inny student)

W końcu mogliśmy mówić, co naprawdę myślimy.

OSKAR

(zakłopotany) Dlaczego... dlaczego nic nie mówicie? Tak bardzo chcę usłyszeć wasze głosy...

MONIKA, PAULINA (razem)

Przecież mówimy. (chwila ciszy) Tylko słuchaj... (kolejna chwila ciszy) Co znowu się tobie nie podoba?

Oskar stoi, jakby nic nie słyszat.

\section{Lekcja 3}

Temat: Halucynacje $\mathrm{e}^{3}$

Paulina i Oskar stoją obok siebie. Na ziemi leża porozrzucane kartki. Oskar i Paulina mówią na dwa głosy, patrza nad głowami publiczności

3 Wiersz ten stanowi zmodyfikowany fragment opublikowanego artykułu (Szwabowski, Wężniejewska 2017). Prezentowany na scenie, na dwa głosy, nabrał innego znaczenia. Co też znalazło wyraz w innym zapisie graficznym. Zdajemy sobie również sprawę, że zapis nie jest tym, co 


\section{OSKAR}

nakładające się przypadkowe narracje

które nie oznaczają zgody

wielogłosowość - bo nie wziąłem tabletek

cisza jest obelga

odmową i oporem

ucieczki w milczenie

Pozór

że się anagażuje

ktoś w coś

że polityka, pedagogika, emancypacja i nauka

że grafomania

i parę wyciągniętych dłoni

wiele do
PAULINA

Pozór

Że się robi

potakiwania

bo milczenie jest zimne

ucieczki w mówienie

osobiste mistyfikacje rzeczywistości

coś się zmienia,

się coś przekształca w coś

coś w ktoś

że prawda

że udawanie

kilka słów

pomiędzy

wiele nici do przecięcia

\section{Za kurtyną}

Powiedziano nam, że tekst nie może się skończyć tak, jak skończyło się wystąpienie. Musimy to jakoś zamknąć. Chociaż chcieliśmy to zostawić otwarte, zawieszone. Programowo unikając podsumowań. Te trzy kropki, które wcześniej zostawiliśmy jako zakończenie, to chwila, kiedy opada kurtyna, robi się ciemno i wtedy jest przestrzeń, w której sobie ktoś coś może poukładać, dopisać, odpowiedzieć. Programowo piszemy teksty, które są niedokończone, fragmentaryczne, a może dzięki temu otwarte.

odegrane (Saldaña 2006: 1019). Nie bez znaczenia było również wypowiedzenie tego w języku polskim. Brzmienia i znaczenia, praca ciała, porozumienie było inne, gdy mówiliśmy w języku, który zamieszkujemy. 
Wybraliśmy taką formę prezentowania naszych doświadczeń nieprzypadkowo. Dla wieloznaczności, dla uniknięcia technologicznego opisu. Bez sugerowania, że zdobywamy jakąś wiedzę. Chcieliśmy wywołać pewne efekty, wciągnąć salę w nasze przeżycia i raczej postawić pytanie - co się wydarzyło?

Jako autoetnografowie prowokujemy. Pisanie jest bardziej formą rozchwiania znaczeń niż ich ustalania. Wytrącania z komfortu znanego. Samo pisanie zaś jest pretekstem do współbycia inaczej.

Będąc na scenie, też prorokowaliśmy. Jak to autoetnografiowie.

Mówi Paulina, a Oskar szepcze w nawiasach:

To był spektakl.

Jednak choć mieliśmy przypisane role, to pozostaliśmy sobą. Po wszystkim patrzymy na publiczność z trwogą i nadzieją. W głowie rodzą się niezliczone pytania:

Czy zrozumieli? Czy już wiedzą? Co o tym myślą? Co zrozumieli? Czy już możemy usiąść?

Twarze na sali są raczej radosne, zaintrygowane - tyle mówią ciała (Paulina była odważniejsza. Patrzyła na salę. Ja spoglądałem nad głowami. Zawstydzony. Dłonie mi się jeszcze trzęsły. Pociłem się. Chciałem zapalić).

„Czy ktoś chce zadać pytanie, a może coś powiedzieć?”.

Ręka unosi się do góry. Mikrofon zostaje oddany publiczności.

„To co pani powiedziała. To o edukacji. Bardzo mi się podoba. Zgadzam się”.

Mówiąc, rozgląda się po sali. Głowy innych uczestników konferencji wyrażają aprobatę.

„Ciekawe jest to, że musimy odszkolnić nasze myślenie. Mam tak samo... nauczyć się myśleć nie po szkolnemu”.

Patrzymy na siebie. Biorę mikrofon. „Tak to jest bardzo ważne...”. Milknę (daję mówić Paulinie. To był jej pomysł. Niech się tłumaczy. Nie wiem zresztą, czy byłbym w stanie coś odpowiedzieć).

Kolega mówi, że „to było dobre, to było to! Gratuluję”. Zdenerwowanie ustępuje radości, to było to... o to nam chodziło (muszę iść zapalić).

„Co to za metoda?” - z zaciekawieniem pytają mnie dwie panie.

„To jest autoetnografia...” - chcę ująć to jak najlepiej. Tak chcę je przekonać do naszej metody: „To jest taka metoda, przy której wykorzystaniu można mówić prosto z serca (Kępa 2014). Takie jest założenie. Mówić prawdę”.

Panie spoglądają na siebie.

„Ciekawe... bardzo ciekawe, ale u nas nie... u nas to by nie przeszło. Nie wolno... tak wprost".

Czas nagli. Idę do toalety. Oskar zostaje na sali. Stoję przy lustrze, myję ręce, widzę, że pani obok zerka na mnie. Zerkam i ja, uśmiecham się do niej. 
„Muszę to powiedzieć. Gratuluję! Bardzo mi się podobało to, co pokazaliście. I ta forma. Przemówiło to do mnie".

„Bardzo się cieszę. Bardzo się staraliśmy, żeby pokazać to, co mamy w sercu... żeby... Gdyby pani chciała, to podam pani informacje. Organizujemy taki cykl konferencji. Właściwie planujemy drugą konferencję w takim stylu, o studiowaniu, u nas na uczelni. Gdzie pojawiają się takie autoetnograficzne wystąpienia. Proszę zapisać... Gdyby pani chciała”.

„Bardzo chętnie!”.

Druga konferencja o studiowaniu nie odbyła się nigdy... Ale nasz performance trwa nadal.

\section{Literatura}

Adams E.T., Jones S.H., Ellis C., 2015, Autoethnography, New York: Oxford University Press. Barr M., 2018, Autoethnography as Pedagogy: Writing the " $I$ ” in $I R$, „Qualitative Inquiry" vol. 25, iss. 9-10.

Blalock A.E., Akehi M., 2018, Collaborative Autoethnography as a Pathway for Transformative Learning, „Journal of Transformative Education” vol. 16, iss. 2.

Boyd D., 2008, Autoethnography as a Tool for Transformative Learning About White Privilege, "Journal of Transformative Education" vol. 6, iss. 3.

Ciechowska M., 2017, Autoetnografia w badaniach pedagogicznych [w:] Wybrane metody jakościowe w badaniach pedagogicznych, red. M. Ciechowska, M. Szymańska, Kraków: Wydawnictwo Naukowe Akademii Ignatianum.

Denzin N.K., 2003a, The Call to Performance, „Symbolic Interaction” vol. 26, no. 1.

Denzin N.K., 2003b, Reading and writing performance, „Qualitative Research” vol. 3, iss. 2.

Denzin N.K., 2009, Qualitative inquiry under fire. Toward a new paradigm dialogue, California: Left Coast Press.

Denzin N.K., 2017, A Manifesto for Performance Autoethnography, „International Review of Qualitative Research" vol. 10, iss. 1.

Guttorm H.E., 2012, Becoming-(a)-paper, or an article undone: (Post-)knowing and writing (again), nomadic and so messy, „Qualitative Inquiry” vol. 18, iss. 7.

Herrmann A.F., 2014, Ghosts, Vampires, Zombie, and Us. The Undead as Autoethographic Bridges, „International Review of Qualitative Research” vol. 7, iss. 3.

Kaczmarczyk P., Madys A., Pławski M., Szczepaniak C., Szwabowski O., Wężniejewska P., [w druku], Kolektywne majsterkowanie albo zmiana, która nie-nadchodzi [w:] Autoetnograficzne „zblizenia” i „oddalenia”. O autoetnografii w Polsce, red. M. Kafar, A. Kacperczyk, Łódź: Wydawnictwo Uniwersytetu Łódzkiego.

Kępa E., 2014, Autoetnografia nie wzięła się znikąd, „Parezja. Czasopismo Forum Młodych Pedagogów Przy Komitecie Nauk Pedagogicznych PAN” nr 1.

Kubinowski D., 2013, Idiomatyczność, synergia, emergencja. Rozwój badań jakościowych w pedagogice polskiej na przełomie XX i XXI wieku, Lublin: Wydawnictwo Makmed.

Lordon F., 2012, Kapitalizm, niewola i pragnienie. Marks i Spinoza, tłum. M. Kowalska, M. Kozłowski, Warszawa: Książka i Prasa. 
Malewski M., 2010, Od nauczania do uczenia się. O paradygmatycznej zmianie w andragogice, Wrocław: Wydawnictwo Naukowe Dolnośląskiej Szkoły Wyższej.

Pelias R.J., 2005, Performative Writing as Scholarship: An Apology, an Argument, an Anecdote, „Cultural Studies $\leftrightarrow$ Critical Methodologies” vol. 5, iss. 4 .

Pławski M., Szwabowski O., Szczepaniak C., Wężniejewska P., 2019, Friendly writing as non-inquiry: The problems of collective autoethnographic writing about collective autoethnographic writing, „Qualitative Inquiry” vol. 25, iss. 9-10.

Richardson L., 2002, Writing Sociology, „Cultural Studies $\leftrightarrow$ Critical Methodologies” vol. 2, iss. 3.

Saldaña J., 2006, This Is Not a Performance Text, „Qualitative Inquiry” vol. 12, iss. 6.

Spry T., 2001, Performing autoethnography: An embodied methodological praxis, „Qualitative Inquiry" vol. 7, iss. 6 .

Stańczyk P., 2010, Milczaca zgoda, kultura ciszy i polityka głosu, „Teraźniejszość-CzłowiekEdukacja. Kwartalnik Myśli Społeczno-Pedagogicznej” nr 3.

Sykes B.E., 2014, Transformative Autoethnography. An Examination of Cultural Identity and its Implications for Learners, „Adult Learning” vol. 25, iss. 1.

Szwabowski O., 2016, Gra w Uniwersytet. „Virtual U” jako menedżerska maszyna dydaktyczna, „Zeszyty Naukowe Collegium Balticum” t. 10.

Szwabowski O., 2019, Nekrofilna produkcja akademicka i pieśni partyzantów. Autoetnografia pracy akademickiej i dydaktycznej w czasach zombie-kapitalizmu, Wrocław: Wydawnictwo Instytutu Pedagogiki Uniwersytetu Wrocławskiego.

Szwabowski O., Wężniejewska P., 2017, An (co)autoethnographic story about going against the neoliberal didactic machine?, „Journal for Critical Education Policy Studies” vol. 15, no. 3.

Ulmer J.B., 2017, Critical Qualitative Inquiry Is/as Love, „Qualitative Inquiry” vol. 23, iss. 7. Waite D., 2014, Teaching the Unteachable: Some Issues of Qualitative Research Pedagogy, „Qualitative Inquiry” vol. 20, iss. 3.

Winker I., 2018, Doing Autoethnography: Facing Challenges, Taking Choice, Accepting Responsibilities, „Qualitative Inquiry” vol. 24, iss. 4.

\section{Streszczenie}

To jest performatywny tekst - zapis autoetnograficznego performance'u dotyczącego dydaktyki akademickiej. Pokazujemy dynamikę pracy podczas projektu „Autoetnografie studiowania”. Był to projekt dydaktyczny prowadzony przez kilka lat. Nasza prezentacja dotyczy najbardziej rozbudowanej i najowocniejszej jego realizacji w latach 2015/2016 (szerzej zob. Szwabowski, Wężniejewska 2017; Szwabowski 2019; Kaczmarczyk et al. [w druku]). W ramach projektu wykorzystano autoetnografię zarówno jako narzędzie dydaktyczne, jak również jako metodę badawczą. Studentki i studenci mieli stać się badaczami swojego życia (Richardson 2002) akademickiego - którym jesteśmy „życi”. Z odbiorców wiedzy przekształcić się mieli w jej producentów. Mieli przestać wyczekiwać, aż ktoś zacznie snuć im małe opowieści o tym, jakie ich życie jest i jak powinno wyglądać, opowieści o tym, kim są i kim powinni być, to znaczy: co powinni myśleć. Mieli spróbować spojrzeć na siebie okiem badacza, wyjść poza mury wytworzonego przez znaczenia świata, spróbować odczytać go i siebie w nim na nowo. 
Tekst został zaprezentowany na konferencji dotyczącej dydaktyki akademickiej. Zamiast przygotować typowy referat, postanowiliśmy pokazać, jak to się odbywało. Pokazać proces tworzenia znowu. Po raz kolejny. Tym razem jednak nie na papierze (nie w formie artykułu), lecz na żywo, z udziałem naszych ciał i towarzyszących nam emocji. To jedna z wielu opowieści. Powtórzenie - znowu inne (zob. Szwabowski 2019; Wężniejewska, Szwabowski 2017; Kaczmarczyk et al. [w druku]).

Tekst składa się z opisu procesu jego tworzenia. Elementu performansu (wystąpienia na konferencji, któremu nadaliśmy formę przedstawienia teatralnego). Na zakończenie wyjaśniamy raz jeszcze nasze stanowisko odnośnie roli tekstu/przedstawienia oraz staramy się zwerbalizować emocje, które nam towarzyszyły, a także prezentujemy głosy innych osób.

\title{
Słowa kluczowe
}

autoetnografia, głosy, edukacja wyższa, dydaktyka

\author{
Summary \\ Didactics on the stage: \\ Performative autoethnography of students' and lecturers' performances
}

This is a performative text - a record of an autoethnographic performance on academic didactics. We show the dynamics of work during the "Autoethnographies of Study" project. It was a didactic project conducted over several years. Our presentation concerns the most extensive and the most fruitful of its implementations in 2015/2016 (for more see Szwabowski 2019; Szwabowski, Wężniejewska 2017; Kaczmarczyk et al. [in print]). The project used autoethnography both as a teaching tool and as a research method. Students were to become researchers into their academic life. They were to transform themselves from recipients of knowledge into producers.

The following text was presented at a conference on academic didactics. Instead of preparing a typical paper, we decided to show how it was done. Again. Once again. This is one of many stories. Repetition - different again.

The text consists of a description of the process of its creation. Element of proper performance. Finally, we explain once again our position regarding the role of the text/ performances and recall the emotions that accompanied us and the voices that came to us.

\section{Keywords}

autoethnography, voices, higher education, didactics 